\title{
Ability of mathematical models to predict faecal output with a pulse dose of indigestible marker
}

\author{
BY P. SUSMEL, B. STEFANON*, M. SPANGHERO AND C. R. MILLS \\ Dipartimento di Scienze della Produzione Animale, Facoltà di Agraria, Università degli studi di \\ Udine, via S. Mauro 2, 33010 Pagnacco, Udine, Italy
}

(Received 30 November 1994 - Revised 9 May 1995-Accepted 4 July 1995)

\begin{abstract}
The aim of the work was to compare the faecal output and digestibility estimated by two mathematical approaches with the actual amount of faeces excreted or feed digested by Simmental cows. Experimental data (intakes and digestibility measured over $5 \mathrm{~d}$ ) and faecal $\mathrm{Cr}$ concentrations (measured at $0,4,8,12$, $16,24,32,48,56,72,96,120$ and $144 \mathrm{~h}$ after a pulse dose of $\mathrm{Cr}$-mordanted forage) were collected from published experiments and fitted to a multicompartmental (MC) model and a $\gamma$ age-dependent (AD) model. From a statistical point of view, the MC model was very satisfactory while the AD model produced lower $\boldsymbol{r}^{2}$ and higher SE values and reached satisfactory statistical values only for higher DM intakes (lactating animals). The MC model produced higher correlations with the digestibility values while the AD model generated better correlations with the intake data; DM intake and digestibilities were more highly correlated with the model's parameters than neutral-detergent fibre terms. The regression between the estimated faecal outputs obtained with the two models showed an intercept close to $0(P>0.05)$ and angular coefficients near 1; there was a good correspondence of the estimates especially for the lowest values of output. The $r^{2}$ values of the regressions were 0.800 and 0.829 for the MC and AD models respectively and their SE were 2.93 and 2.63 . The ability of the two models to predict faecal output and digestibility was very similar, independent of the statistical accuracy of fitting the $\mathbf{C r}$ concentration data. The results indicate that variation of $\mathrm{Cr}$ concentration is the result of the entire digestive process, i.e. dilution and passage, which interact in a competitive or associative way.
\end{abstract}

Mathematical models: Faecal output: Cattle

Indigestible markers, such as $\mathrm{Cr}$-mordanted feeds, have been used widely for the estimation of the rumen transit time of diets (Grovum \& Williams, 1973; Uden et al. 1980; Stern et al. 1983; Colucci et al. 1984; Eliman \& Ørskov, 1984; Ellis et al. 1984; France et al. 1985; Stefanon \& Ovan, 1988; Cruickshank et al. 1989; Ramanzin et al. 1990, 1991 b; Susmel et al. 1990b, 1991, 1994a, $b$; Stefanon et al. 1992). The method requires the administration of a single pulse dose of a limited amount of marker and the analysis of the excretion pattern in the faeces with appropriate mathematical models. The most frequently used models are dual compartmental (Grovum \& Williams, 1973) with two rates of decay, the slowest being associated with the rumen and the fastest with post-rumen passage. Other mathematical models such as the $\gamma$ family, multicompartmental or algebraic models have been studied to improve the description of marker excretion curves (Pond et al. 1984; Dhanoa et al. 1985; Quiroz et al. 1988; Susmel et al. 1990 a; Lallés et al. 1991). However, the treatment of feeds with, for example, $\mathrm{Cr}$ results in a change in their degradability (Robles et al. 1981; Stefanon \& Ovan, 1988) and physico-chemical properties (Ehle, 1984; Ehle et al. 1984; Ramanzin et al. 1991 $a$; Owens \& Hanson, 1992), and this could lead to a bias in the prediction of the rumen transit time.

\footnotetext{
* For reprints.
} 
A pulse dose of a known amount of indigestible marker and the description of the faecal marker concentration curve can also be used to estimate faecal output (France et al. 1988). In this case, all that is required is to compute the area under the faecal marker concentration curve and calculate the dose:area ratio. If the DM intake is known this method allows the estimation of the digestibility of a diet (Aitchison et al. 1986; Krysl et al. 1988; Susmel et al. 1992 b).

The aim of the work described in the present paper was to compare the estimated faecal output and digestibility predicted using two mathematical models with the actual amount of faeces excreted or feed digested by cows fed on diets differing in terms of feed composition and DM intake.

\section{MATERIALS AND METHODS}

Experimental data were collected from published experiments (Susmel et al. 1992a, 1994a, b) performed on Simmental cows, housed in a barn equipped for individual feeding and faeces and urine collection. Diet composition and methodological aspects are reported in the papers and summarized in Table 1.

In Expt 1 (diet 1), four cows were given $5.44 \mathrm{~kg} \mathrm{DM} / \mathrm{d}$ wheat straw, supplemented with soyabean meal $(0.71 \mathrm{~kg} \mathrm{DM} / \mathrm{d})$, maize and barley $(1.14 \mathrm{~kg} \mathrm{DM} / \mathrm{d})$ and $60 \mathrm{~g}$ urea/d. In Expt 2 (diet 2), three cows, in four consecutive periods, were fed on diets containing fescue (Festuca arundinacea) hay alone $(7.48 \mathrm{~kg} \mathrm{DM} / \mathrm{d}$ ) or fescue hay and an increasing amount of soyabean meal $(0.35,0.70$ and $1.05 \mathrm{~kg} \mathrm{DM} / \mathrm{d}$ soyabean replaced the same amount of fescue hay). In Expt 3 (diet 3), six cows were given $7.68 \mathrm{~kg} \mathrm{DM} / \mathrm{d}$ fescue hay, $2.65 \mathrm{~kg} \mathrm{DM} / \mathrm{d}$ maize and an increasing amount of urea $(60$ and $120 \mathrm{~g} / \mathrm{d})$ in three periods. Expts 1, 2 and 3 were performed with rumen-cannulated, non-lactating Simmental cows. Expt 4 (diet 4) was conducted with lactating animals, receiving $a d$ lib. a ration of fescue hay and concentrate in a ratio of 50:50 on a DM basis. All diets were administered in two equal meals, at 07.30 and 17.00 hours.

In the passage-rate studies, the same forage used in the ration (i.e. straw or fescue hay) was mordanted with $40 \mathrm{~g}$ sodium dichromate $/ \mathrm{kg}$ (Uden et al. 1980) and chopped to approximately $50 \mathrm{~mm}$ length. The $\mathrm{Cr}$ concentrations of mordanted forages were $5 \cdot 90,7 \cdot 60$, 4.62 and $7.20 \mathrm{~g} / \mathrm{kg} \mathrm{DM}$ for diets $1-4$ respectively.

A known amount ( $250 \mathrm{~g}$ fresh weight per cow) of mordanted forage was administered before the morning meal to each cow, either directly via the fistula or mixed with the concentrate feed. Faecal grab samples were collected after $0,4,8,12,16,24,32,48,56,72$, 96,120 and $144 \mathrm{~h}$, oven-dried and analysed for $\mathrm{Cr}$ with atomic absorption spectrophotometry. In order to compare the $\mathrm{Cr}$ excretion curves between the four trials, the actual faecal concentration was multiplied by the DM intake before the statistical analysis was run.

Data were fitted to a multicompartmental (MC) model (Dhanoa et al. 1985) and a $\gamma$ agedependent (AD) model (Ellis et al. 1979), using a non-linear, iterative procedure (Statistical Package for the Social Sciences, 1988). The two models can be written thus:

$$
\begin{gathered}
y_{M C}=A \mathrm{e}^{-k_{1}(t-T)} \mathrm{e}^{-(N-2) \mathrm{e}^{\left(k_{2}-k_{1}\right)(t-T)},} \\
y_{A D}=\frac{A}{0.59635} L(t-T) \mathrm{e}^{-L(t-T)},
\end{gathered}
$$

where $y$ is the marker concentration at time $t(\mathrm{mg} / \mathrm{kg} \mathrm{DM}) ; k_{1}$ and $k_{2}$ are assumed to be 
Table 1. Live weights, DM and neutral-detergent fibre (NDF) intakes and digestibilities measured during experiments with Simmental cows (data from Susmel et al. 1992a, $1994 a, b)$

\begin{tabular}{|c|c|c|c|c|c|}
\hline & \multirow[b]{2}{*}{ Live wt $(\mathrm{kg})$} & \multicolumn{2}{|c|}{ Intakes $(\mathrm{kg} / \mathrm{d})$} & \multicolumn{2}{|c|}{ Digestibility (\%) } \\
\hline & & DM & NDF & DM & NDF \\
\hline \multicolumn{6}{|c|}{ Diet 1. Straw + concentrate ( $n 4$ observations) } \\
\hline Mean & 659 & $7 \cdot 26$ & $5 \cdot 18$ & $60 \cdot 7$ & $59 \cdot 9$ \\
\hline SD & 73 & $0 \cdot 23$ & $0 \cdot 20$ & $1 \cdot 4$ & 1.6 \\
\hline Range: $\min$ & 580 & $6 \cdot 92$ & $4 \cdot 88$ & $59 \cdot 2$ & $57 \cdot 9$ \\
\hline $\max$ & 736 & $7 \cdot 40$ & $5 \cdot 30$ & $62 \cdot 4$ & $61 \cdot 4$ \\
\hline \multicolumn{6}{|c|}{ Diet 2. Hay + soyabean ( $n 12$ observations) } \\
\hline Mean & 659 & $7 \cdot 42$ & $4 \cdot 63$ & $62 \cdot 9$ & $61 \cdot 6$ \\
\hline SD & 34 & $0 \cdot 20$ & $0 \cdot 29$ & $2 \cdot 1$ & $2 \cdot 5$ \\
\hline Range: $\min$ & 591 & 6.95 & 3.96 & $59 \cdot 8$ & $58 \cdot 4$ \\
\hline $\max$ & 700 & $7 \cdot 61$ & 5.02 & $66 \cdot 6$ & $65 \cdot 6$ \\
\hline \multicolumn{6}{|c|}{ Diet 3. Hay + maize ( $n 18$ observations) } \\
\hline Mean & 671 & $10 \cdot 25$ & $4 \cdot 76$ & $72 \cdot 6$ & $64 \cdot 3$ \\
\hline SD & 52 & $0 \cdot 14$ & 0.08 & $2 \cdot 3$ & $3 \cdot 4$ \\
\hline Range: $\min$ & 575 & $9 \cdot 82$ & $4 \cdot 53$ & $67 \cdot 1$ & $58 \cdot 8$ \\
\hline $\max$ & 747 & $10 \cdot 32$ & $4 \cdot 80$ & $76 \cdot 2$ & $69 \cdot 9$ \\
\hline \multicolumn{6}{|c|}{ Diet 4. Hay + concentrate ( $n 8$ observations) } \\
\hline Mean & 593 & $14 \cdot 30$ & $7 \cdot 28$ & $68 \cdot 2$ & $60 \cdot 7$ \\
\hline SD & 31 & 0.61 & $0 \cdot 54$ & $2 \cdot 3$ & $3 \cdot 0$ \\
\hline \multirow{2}{*}{ Range: $\min _{\max }$} & 557 & 13.44 & $6 \cdot 51$ & $63 \cdot 7$ & $55 \cdot 8$ \\
\hline & 655 & $15 \cdot 23$ & $8 \cdot 09$ & $70 \cdot 9$ & $65 \cdot 2$ \\
\hline
\end{tabular}

the constant rates of passage, per $\mathrm{h} ; L$ is the age-dependent passage rate, per $\mathrm{h} ; \mathrm{N}$ is the number of compartments; $T$ is the time delay (h) before the first appearance of marker in the faeces; $A$ is a scale parameter.

The compartment mean retention time (CMRT, h) was calculated from $1 / k_{1}$ and $2 / L$ and the total mean retention time (TMRT, h) was calculated from $\left(1 / k_{1}+1 / k_{2}\right)+T$ and $2 / L+T$ for the two models respectively.

The amount of marker, $\mathrm{dM}$, excreted in a time, $\mathrm{dt}$, can be defined as:

$$
\mathrm{dM}=C(t) F_{\mathrm{op}} \mathrm{dt},
$$

where $C(t)$ is the concentration of the marker at time $t$ and $F_{\text {op }}$ is the faecal output. In a defined time interval $\Delta t$, ranging from $t_{1}$ to $t_{2}$, the amount of marker excreted $(\mathrm{M})$ is:

$$
\mathrm{M}=\int_{t_{1}}^{t_{2}} \mathrm{~d} \mathbf{M}=\int_{t_{1}}^{t_{2}} C(t) F_{\mathrm{op}} \mathrm{dt} \approx \sum_{t_{1}}^{t_{2}} F_{\mathrm{op}} C(t) \Delta t .
$$

Only if the faecal output is constant, as is generally assumed (France et al. 1993), can the following equation be written:

$$
\mathbf{M}=F_{\mathrm{op}} \int_{t_{1}}^{t_{2}} C(t) \mathrm{dt} .
$$

In the time interval which allows all the marker administered (D) to flow out in the faeces 
(M) and assuming that it is completely recovered, it is possible to compute the faecal output $\left(F_{\text {op }}\right)$ from the equation:

$$
F_{\mathrm{op}}=D / \int_{t_{1}}^{t_{2}} C(t) \mathrm{dt} .
$$

The results presented were obtained with the integral from 0 to $300 \mathrm{~h}$; the ratio between dose and the integral value was multiplied by 24 to express it on a daily basis.

\section{RESULTS}

Intake and digestibility data are reported in Table 1; diets 1 and 2 were fed at a low level (approximately $10 \mathrm{~g} \mathrm{DM} / \mathrm{kg}$ live weight) and diet 3 at a higher level (approximately $15 \mathrm{~g} \mathrm{DM} / \mathrm{kg}$ live weight). Diet 4 , based on fescue hay and concentrate, was fed to lactating cows at a level of about $25 \mathrm{~g} \mathrm{DM} / \mathrm{kg}$ live weight. DM digestibility was higher for the hay + maize diet than that fed to lactating animals, and lower digestibility values were observed for the other two diets. The neutral-detergent fibre (NDF) digestibility did not follow the same trend: only in the hay + maize diet was the NDF digestibility higher.

A first attempt to perform non-linear analysis of the faecal $\mathrm{Cr}$ excretion with the $\mathrm{MC}$ model was conducted with constraints for positive values for the parameters, but in some cases the calculated $T$ was much higher than the observed value; moreover $A, N$ and $T$ were highly autocorrelated. In order to obtain a more biologically correct estimate of the time delay, the analysis was rerun with the constraint that $T$ could not exceed twice the observed value. $A, N$ and $T$ varied widely but no significant variations of $r^{2}$ or residual SE were observed and $k_{1}$ and $k_{2}$ remained constant. Again, the correlation matrix revealed a high degree of autocorrelation. However, the use of these latter parameter values was considered more appropriate and they were used for the subsequent statistical analysis.

The results obtained with the MC model (Table 2) showed that $A, N$ and $T$ varied widely between and within diets, while smaller differences were observed for $k_{1}$ and $k_{2}$. The number of compartments $(N)$ was very low in the straw diet and higher in the hay + maize and hay + soyabean diets; $T$ (time delay before the first appearance of marker in the faeces) was very high only in the straw + concentrate diet, remaining almost constant in the other three diets. The calculated compartment and total mean retention times (CMRT and TMRT) were, on average, not very variable between diets, even though the lowest values were observed in diets 3 and 4 with the highest DM intake levels; however, the range within each experiment reflected a high variability between animals. From a statistical point of view the MC model was very satisfactory for all diets and cows.

Faecal Cr-concentration data were also fitted to the AD model, using different orders of $\gamma$-dependency (from 2 to 4); increasing the $\gamma$ order gave a better fit, but $T$ was often zero and the autocorrelation between parameters increased (from $0.2-0.3$ to $0.7-0.8$ ); the value of the age-dependent passage rate also changed. In Table 3, only the parameters obtained with the 2 nd order model are reported. $A$ and $L$ varied within and between diets and the latter increased with the plane of nutrition. The use of the AD model produced lower $r^{2}$ and higher SE values than the age-independent model (MC) and only reached satisfactory statistical values for lactating animals.

With the AD model, the $A$ values were lower and the CMRT and TMRT were always higher than those obtained with the MC model; increasing the level of intake (from diet 1 to 4) decreased both the CMRT and TMRT.

In Figs 1 and 2 the typically different shapes of the fitted curves are presented. In Fig. 3 , where the different ability of the models to fit the observed $\mathrm{Cr}$ concentrations is shown (data refer to one cow), the poorer fit given by the AD model, especially in terms of the peak 
Table 2. Kinetic parameters of the chromium concentration in the faeces, compartment $(C M R T)$ and total mean retention time $(T M R T)$ and estimated faecal output $\left(\mathrm{F}_{o p}\right)$ : multicompartmental model (Eqn 1)

\begin{tabular}{|c|c|c|c|c|c|c|c|c|c|c|}
\hline Trial & $A$ & $k_{1}$ & $k_{2}$ & $N$ & $T$ & $r^{2}$ & $\mathrm{SE}$ & CMRT & TMRT & $F_{\mathrm{op}}$ \\
\hline \multicolumn{11}{|c|}{ Diet 1 . Straw + concentrate ( $n 4$ observations) } \\
\hline Mean & 1767 & 0.023 & 0.109 & 3.91 & 21.95 & 0.973 & 61.76 & $44 \cdot 70$ & 57.85 & $4 \cdot 39$ \\
\hline SD & 743 & 0.001 & 0.009 & $1 \cdot 15$ & 7.27 & 0.018 & $41 \cdot 57$ & 10.91 & 9.74 & 0.41 \\
\hline Range: $\min$ & 1107 & 0.017 & 0.095 & $2 \cdot 72$ & 14.31 & 0.951 & 22.04 & 32.68 & $46 \cdot 88$ & 3.93 \\
\hline $\max$ & 2829 & 0.031 & 0.115 & $5 \cdot 35$ & 30.08 & 0.990 & 94.86 & $59 \cdot 17$ & $70 \cdot 60$ & 4.75 \\
\hline \multicolumn{11}{|c|}{ Diet 2. Hay + soyabean ( $n 12$ observations) } \\
\hline Mean & 2855 & 0.025 & 0.096 & 8.86 & 5.66 & 0.983 & 50.51 & $41 \cdot 42$ & 61.68 & 3.88 \\
\hline SD & 1816 & 0.006 & 0.037 & 2.02 & 5.04 & 0.011 & $28 \cdot 16$ & 8.83 & 8.68 & 0.33 \\
\hline Range: $\min$ & 1108 & 0.017 & 0.059 & 5.95 & 0.00 & 0.951 & $20 \cdot 14$ & $29 \cdot 16$ & $49 \cdot 17$ & 3.47 \\
\hline $\max$ & 7241 & 0.034 & 0.200 & $11 \cdot 49$ & $15 \cdot 00$ & 0.998 & $113 \cdot 74$ & $57 \cdot 47$ & 78.72 & $4 \cdot 42$ \\
\hline \multicolumn{11}{|c|}{ Diet 3. Hay + maize ( $n 18$ observations) } \\
\hline Mean & 10256 & 0.033 & 0.107 & 8.90 & $2 \cdot 72$ & 0.986 & 77.97 & $31 \cdot 24$ & $49 \cdot 65$ & 2.85 \\
\hline SD & 3049 & 0.001 & 0.016 & 1.75 & 2.54 & 0.011 & $58 \cdot 58$ & 6.02 & 6.96 & 0.39 \\
\hline \multirow{2}{*}{ Range: } & 5113 & 0.024 & 0.084 & $6 \cdot 64$ & 0.00 & 0.961 & 19.88 & $22 \cdot 22$ & 38.46 & 2.08 \\
\hline & 16500 & $0 \cdot 045$ & 0.147 & $12 \cdot 44$ & 8.74 & 0.996 & $206 \cdot 58$ & $41 \cdot 49$ & $60 \cdot 33$ & 3.52 \\
\hline \multicolumn{11}{|c|}{ Diet 4 . Hay + concentrate ( $n 8$ observations) } \\
\hline Mean & 6183 & 0.027 & 0.120 & 6.44 & 2.64 & 0.973 & $170 \cdot 67$ & 38.87 & $53-76$ & 3.19 \\
\hline SD & 3098 & 0.001 & 0.017 & $1 \cdot 18$ & 1.83 & 0.018 & $93 \cdot 41$ & $7 \cdot 34$ & 5.87 & 0.28 \\
\hline \multirow[t]{2}{*}{ Range: } & 3397 & 0.021 & 0.093 & 5.09 & 0.00 & 0.951 & 83.06 & $27 \cdot 47$ & $44 \cdot 22$ & 2.86 \\
\hline & 12119 & 0.036 & 0.141 & 8.56 & 4.76 & 0.990 & $368 \cdot 23$ & 48.54 & 60.70 & 3.61 \\
\hline
\end{tabular}

$A$, scale parameter of marker concentration $(\mathrm{mg} / \mathrm{kg} \mathrm{DM}) ; k_{1}$ and $k_{2}$, constant rates of passage $(\mathrm{per} \mathrm{h}) ; N$, number of compartments; $T$, time delay (h); CMRT $=1 / k_{1}(\mathrm{~h}) ; \mathrm{TMRT}=1 / k_{1}+1 / k_{2}+T(\mathrm{~h}) ; F_{\mathrm{op}}$, estimated faecal output ( $\mathrm{kg} \mathrm{DM} / \mathrm{d})$.

concentration, is very clear. The rank of actual DM digestibility followed the peak heights for both models very closely (compare Table 1 and Figs 1 and 2): the highest peak was observed for the hay + maize diet, i.e. the most digestible (diet 3, DM digestibility (DMD) $=72.6 \%$ ) followed by the hay + concentrate diet (diet 4 , DMD $=68.2 \%$ ) and the other two diets had very similar shapes and peak $\mathrm{Cr}$ concentrations (DMD $=62.9$ and $60.7 \%$ for the hay + soyabean, diet 2 , and straw + concentrate, diet 1 respectively).

The different abilities of the models to predict the measured data were investigated by correlation analysis (Table 4) between the parameter $A$, CMRT and TMRT with actual intakes and digestibilities. The $\mathrm{MC}$ model produced higher correlations with the digestibility values while the $\mathrm{AD}$ model generated better correlations with the intake data; DM intake and digestibility were more highly correlated with the model's parameters than NDF terms.

The regression between actual DM digestibility and estimates obtained with the use of integrals were higher and similar for both the models, even though the AD model generally performed better (Figs 4 and 5). The intercepts were not significant and the angular coefficients approximated unity. The $r^{2}$ value was higher and residual SE (RSE) lower for the AD model, but the CV were lower than $4 \%$ for both the models.

The regression between the estimated faecal output with the two models (Fig. 6) showed an intercept close to $0(P>0.05)$ and angular coefficients near 1 ; a good correspondence of the estimates was shown particularly for the lowest values of output. 
Table 3. Kinetic parameters of the chromium concentration in the faeces, compartment $(C M R T)$ and total mean retention time $(T M R T)$ and estimated faecal output $\left(\mathrm{F}_{o p}\right)$ : agedependent model (Eqn 2)

\begin{tabular}{|c|c|c|c|c|c|c|c|c|}
\hline Trial & $A$ & $L$ & $T$ & $r^{2}$ & SE & CMRT & TMRT & $F_{\mathrm{op}}$ \\
\hline \multicolumn{9}{|c|}{ Diet 1. Straw + concentrate ( $n 4$ observations) } \\
\hline Mean & 910 & 0.024 & 3.83 & 0.765 & $193 \cdot 78$ & $84 \cdot 35$ & $88 \cdot 17$ & $3 \cdot 97$ \\
\hline SD & 66 & 0.002 & $0 \cdot 24$ & 0.013 & $45 \cdot 72$ & $7 \cdot 44$ & $7 \cdot 61$ & 0.22 \\
\hline Range: $\min$ & 844 & 0.021 & $3 \cdot 53$ & 0.749 & 166.85 & $75 \cdot 76$ & $79 \cdot 53$ & $3 \cdot 67$ \\
\hline $\max$ & 1000 & 0.026 & $4 \cdot 09$ & $0 \cdot 776$ & $261 \cdot 80$ & 93.46 & $97 \cdot 55$ & $4 \cdot 14$ \\
\hline \multicolumn{9}{|c|}{ Diet 2. Hay + soyabean ( $n 12$ observations) } \\
\hline Mean & 1569 & 0.024 & $7 \cdot 25$ & 0.795 & 57.46 & $85 \cdot 16$ & $92 \cdot 41$ & 3.74 \\
\hline SD & 380 & 0.003 & 0.62 & 0.052 & $41 \cdot 36$ & 13.99 & $14 \cdot 33$ & 0.32 \\
\hline \multirow{2}{*}{ Range: } & 988 & 0.017 & $6 \cdot 27$ & 0.692 & $10 \cdot 47$ & $78 \cdot 43$ & $75 \cdot 61$ & $3 \cdot 29$ \\
\hline & 2243 & 0.029 & $8 \cdot 43$ & 0.868 & 131.87 & $120 \cdot 48$ & $128 \cdot 91$ & $4 \cdot 25$ \\
\hline \multicolumn{9}{|c|}{ Diet 3. Hay + maize ( $n 18$ observations) } \\
\hline Mean & 2530 & 0.031 & $6 \cdot 39$ & 0.832 & $87 \cdot 38$ & $64 \cdot 40$ & $71 \cdot 18$ & $2 \cdot 59$ \\
\hline SD & 272 & 0.003 & $0 \cdot 54$ & 0.026 & $24 \cdot 81$ & 6.81 & $7 \cdot 10$ & $0 \cdot 32$ \\
\hline \multirow[t]{2}{*}{ Range: } & 1980 & $0 \cdot 026$ & $5 \cdot 38$ & 0.775 & $48 \cdot 59$ & $52 \cdot 36$ & $58 \cdot 28$ & 2.06 \\
\hline & 3030 & $0 \cdot 038$ & $7 \cdot 34$ & 0.864 & $133 \cdot 43$ & $72 \cdot 99$ & $83 \cdot 97$ & $3 \cdot 19$ \\
\hline \multicolumn{9}{|c|}{ Diet 4. Hay + concentrate ( $n 8$ observations) } \\
\hline Mean & 2747 & 0.037 & $4 \cdot 71$ & $0-921$ & $429 \cdot 33$ & $54 \cdot 85$ & $59 \cdot 55$ & $3 \cdot 16$ \\
\hline SD & 193 & 0.002 & $0 \cdot 70$ & 0.027 & $228 \cdot 41$ & 3.54 & 3.96 & 0.35 \\
\hline \multirow[t]{2}{*}{ Range: } & 2410 & 0.034 & 3.03 & 0.890 & 153.78 & $49 \cdot 75$ & $52 \cdot 78$ & $2 \cdot 75$ \\
\hline & 2980 & 0.040 & $5 \cdot 17$ & 0.966 & 791.97 & $59 \cdot 52$ & $64 \cdot 60$ & 3.74 \\
\hline
\end{tabular}

$A$, scale parameter of marker concentration $(\mathrm{mg} / \mathrm{kg} \mathrm{DM}) ; L$, age-dependent passage rate (per $\mathrm{h}) ; T$, time delay (h); CMRT $=2 / L(\mathrm{~h}) ; \mathrm{TMRT}=2 / L+T(\mathrm{~h}) ; F_{\mathrm{op}}$, estimated faecal output $(\mathrm{kg} \mathrm{DM} / \mathrm{d})$.

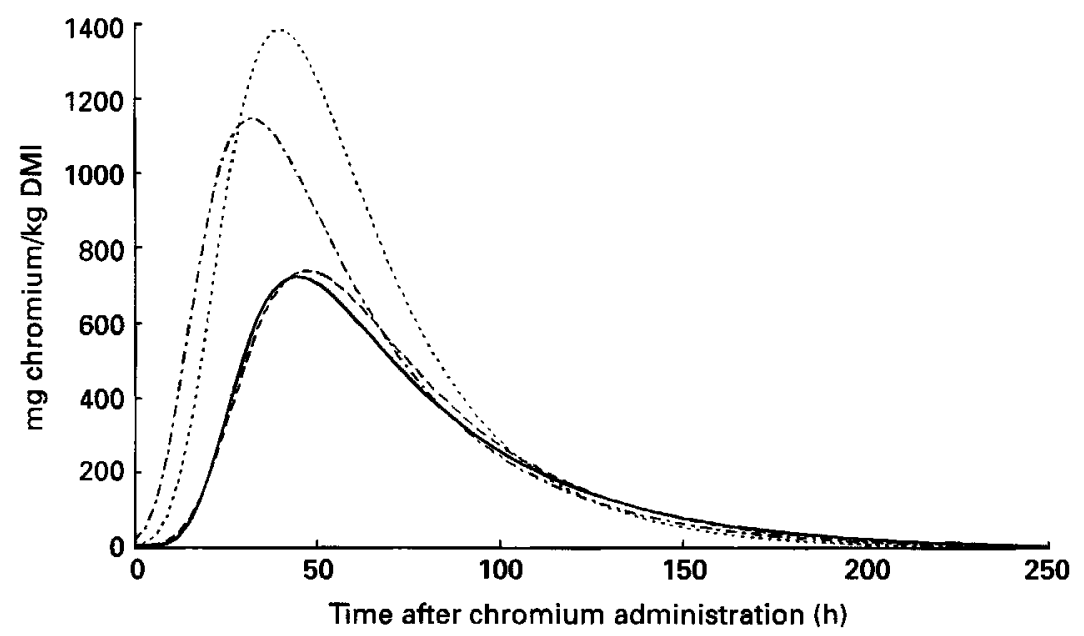

Fig. 1. Pattern of chromium excretion in the faeces: multicompartmental model. (-), Diet 1, (---), diet 2; $(-.-)$, diet $3 ;(-.-)$, diet 4 ; for details of diets see Table 1. DMI, dry-matter intake.

\section{DISCUSSION}

The choice of the MC and AD models (Ellis et al. 1979; Dhanoa et al. 1985) was based on statistical and biological criteria. In previous papers (Susmel et al. 1990a, 1992 b) the ability of different mathematical models (two compartments, multicompartmental, age-dependent, 


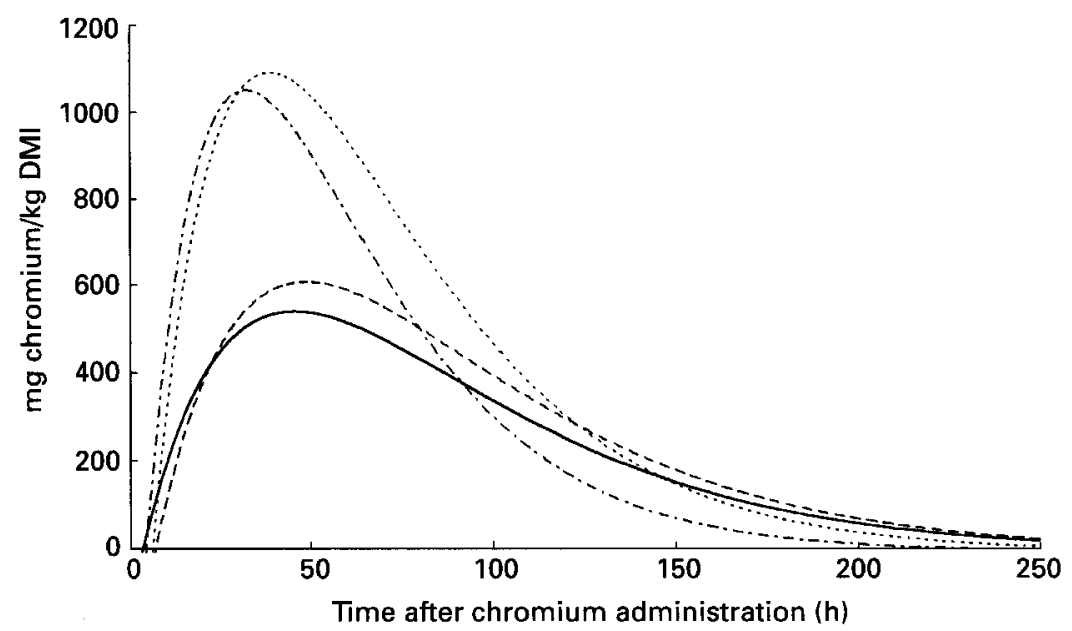

Fig. 2. Pattern of chromium excretion in the faeces: age-dependent model. $(\longrightarrow)$, Diet 1 ; $(---)$, diet $2 ;(---)$, diet $3 ;(-.-)$, diet 4 ; for details of diets see Table 1. DMI, dry-matter intake.

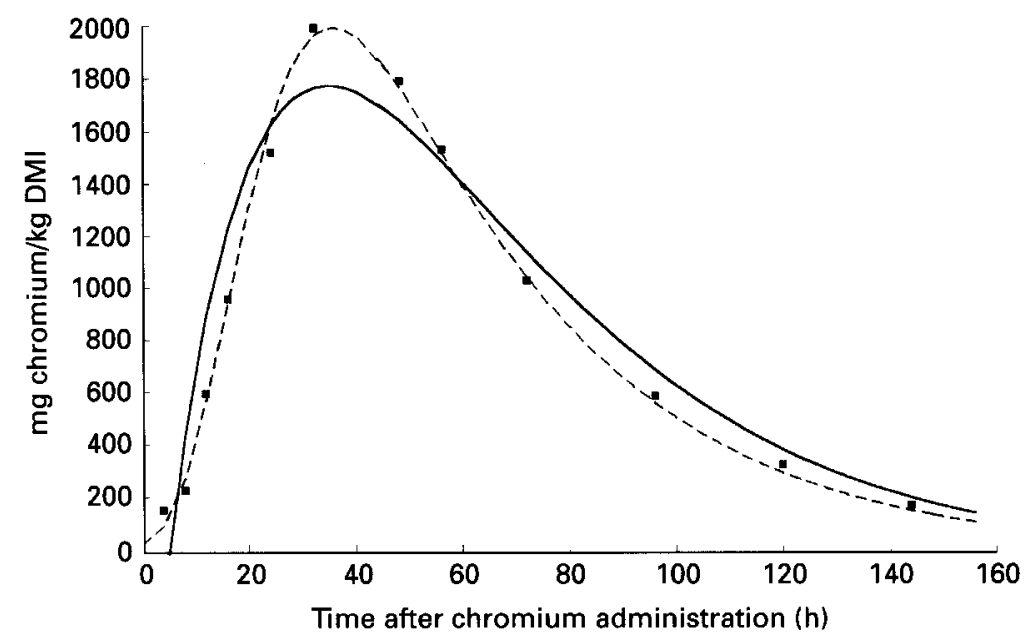

Fig. 3. Pattern of chromium excretion in the faeces: ( $\square$ ), actual values from a single cow; (---), values fitted using the multicompartmental model; $(-)$, values fitted using the age-dependent model. DMI, dry-matter intake.

mixed age-dependent-age-independent) to describe the change of marker concentration in the faeces was investigated. The results showed that for $\mathrm{Cr}$-mordanted forage the $\mathrm{MC}$ model produced better fits (i.e. higher $r^{2}$ and lower RSE), but correlation with rumen degradability or digestibility did not demonstrate any particularly superior model, with MC sometimes performing better than the others, and sometimes worse.

In the present paper the comparison between a relevant statistical model (MC) and a simpler but worse model (AD) was chosen. The MC model gave a statistically better performance than the AD model (Tables 2 and 3 ) and this confirms the observations of other researchers (Dhanoa et al. 1985; Beauchemin \& Buchanan-Smith, 1989; Lallés et al. 1991).

As far as the AD model is concerned, increasing the order of age-dependency leads to a more gradual ascending portion of the curve (Pond et al. 1988) and a decrease of the $T$ 
Table 4. Correlation analysis between dietary and model-based parameters (df 40)

\begin{tabular}{lllll}
\hline \hline & Model & $A$ & CMRT & TMRT \\
\hline DM intake (kg/d) & MC & $0 \cdot 40^{* *}$ & NS & $-0.32^{*}$ \\
& AD & $0 \cdot 79^{* * *}$ & $-0 \cdot 76^{* * *}$ & $-0 \cdot 76^{* * *}$ \\
NDF intake (kg/d) & MC & NS & NS & NS \\
& AD & $0 \cdot 44^{* *}$ & $-0.47^{* * *}$ & $-0.50^{* * *}$ \\
DM digestibility (\%) & MC & $0 \cdot 75^{* * *}$ & $-0 \cdot 41^{* *}$ & $-0 \cdot 40^{* *}$ \\
& AD & $0 \cdot 71^{* * *}$ & $-0 \cdot 56^{* *}$ & $-0.53^{* *}$ \\
NDF digestibility (\%) & MC & $0 \cdot 42^{* *}$ & NS & NS \\
& AD & NS & NS & NS \\
\hline
\end{tabular}

CMRT, compartment mean retention time; TMRT, total mean retention time; $\mathrm{MC}$, multicompartmental model (Eqn 1); AD, age-dependent model (Eqn 2); NDF, neutral-detergent fibre.

$* P<0.05, * * P<0.01, * * * P<0.001$.

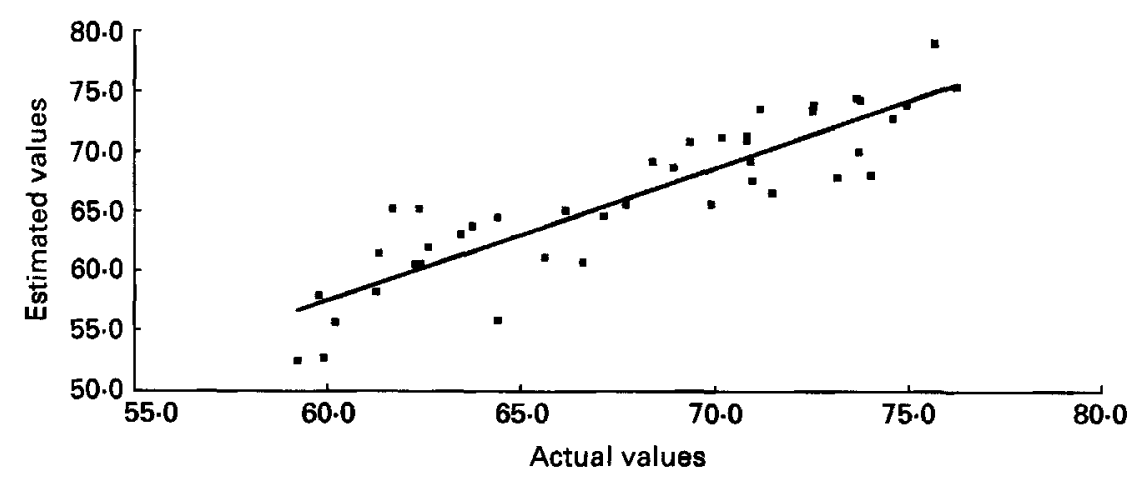

Fig. 4. Regression of actual $v$. estimated dry-matter digestibility: multicompartmental model $\left(y=-9 \cdot 72+1 \cdot 12 x ; r^{2} 0.800, \mathrm{SE} 2 \cdot 93\right)$.

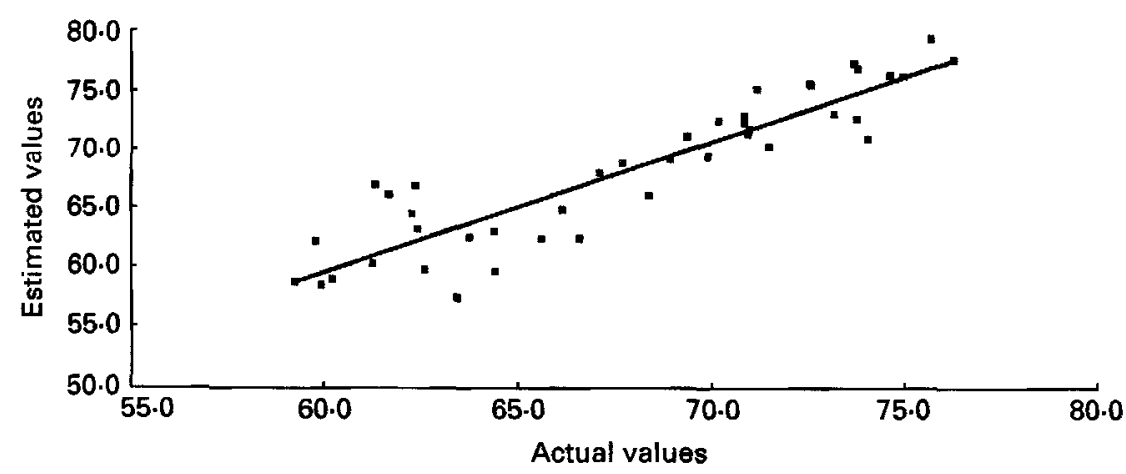

Fig. 5. Regression of actual $v$. estimated dry-matter digestibility: age-dependent model $\left(y=-7.02+1 \cdot 11 x ; r^{2} 0 \cdot 829, \mathrm{SE} 2 \cdot 63\right)$

value to 0 ; for these reasons, different $\gamma$ orders have to be applied to the same dataset in order to find the best estimates. In the present experiment the fitting ability of the AD model with a $\gamma$ order of two was very poor and increased with $\gamma$ order, but the high degree of autocorrelation observed with increasing order of age-dependency indicated that only the order 2 model could be used, independently of the statistical accuracy. 


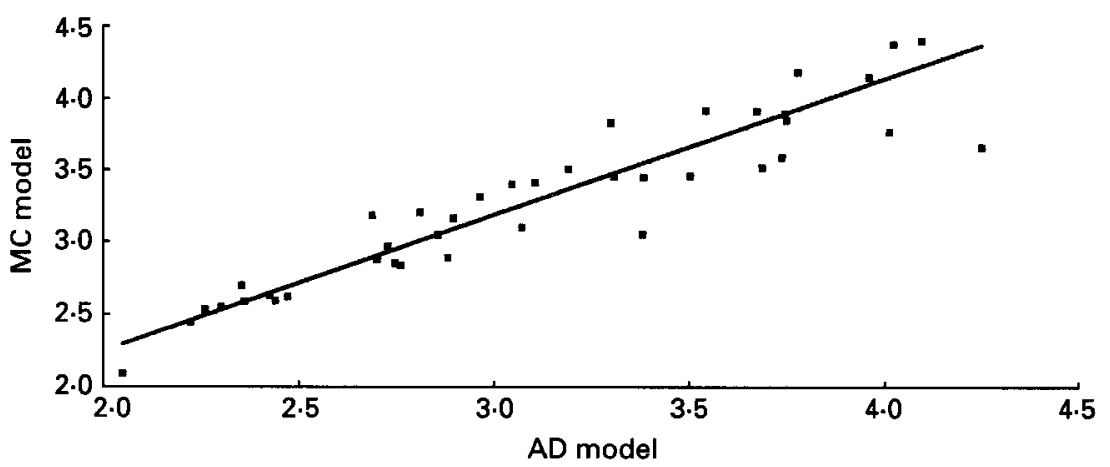

Fig. 6. Regression of faecal output (kg DM/d) estimated by the multicompartmental (MC) model $v$. faecal output measured by the age-dependent (AD) model $\left(y=0.32+0.96 x ; r^{2} 0.868\right.$, SE 0.24$)$.

The identification of the best model to describe the pattern of $\mathrm{Cr}$ excretion in the faeces should be easy from a statistical point of view, as the coefficients of determination, RSE and the distribution of the residuals can be compared (Susmel et al. 1990a); however, it is more difficult to find and verify the biological meaning of the parameters.

According to Dhanoa et al. $(1985,1989), A$ in the MC model is a scale parameter defining $\mathrm{Cr}$ concentrations in the faeces, and is likely to vary with the amount (dose) of marker administered in relation to the amount of DM ingested; $T$ is related to the time of first appearance of marker in the faeces and $N$ represents the number of compartments, which varies according to intake and fibre concentration of the diet. However, in the experiments reported here, these parameters varied widely according to the constraints put on the nonlinear procedure, without modifying the shape of the curve and the $k_{1}$ and $k_{2}$ values. In the AD model, $A$ and $T$ have the same meaning as in the MC model (Pond $e t$ al. 1988), but the large difference observed in the parameter estimates obtained with the two models (Tables 2 and 3) appears to indicate that they have a mathematical rather than a biological significance. The use of an age-dependent model produces a smoother curve and allows negative values of $\mathrm{Cr}$ concentration making $T$ estimates similar between diets which were very different in terms of fibre content (i.e. straw + concentrate and hay + soyabean) and plane of nutrition. Quiroz et al. (1988) reported that the shape of marker excretion curves in the faeces varied according to particle size, reflecting different times and extents of rumination, hydration and microbial degradation; as a result, large particles should have higher $T$ values and less skew than small particles, but the same conclusion cannot be drawn from the present results, where the diets of three trials were based on the same fescue hay.

The difficulty of assigning a precise meaning to each of these parameters has often been reported (Aitchison et al. 1986; Murphy et al. 1989; Lallés et al. 1991; Susmel et al. 1991) and the comparison of the shapes of the curves (Figs 1 and 2) further confirms that the models tended to depict the pattern of marker excretion in a predetermined way: the MC model does not allow negative values for the $y$ axis and is more sensitive in describing the ascending phase and the peak of Cr concentration than the AD model (Fig. 3).

France et al. (1988) and Dhanoa et al. (1989) have stressed the importance of the study of faecal marker concentration curves as a method for estimating ruminal rate of passage and ruminal and total mean retention times. In this approach, $k_{1}$ and $k_{2}$ are assumed to represent the rumen and post-rumen passage rates in the $\mathrm{MC}$ model, and $L$, in the $\mathrm{AD}$ model, is a parameter which takes into account an age-dependent process in the transit of particles along the gastrointestinal tract, due to the imperfect mixing and dilution of the 
marker in the digesta in the various physical compartments of the tract, with their different volumes and sectional diameters, and the increased probability of escape of aged particles (Pond et al. 1988). Rate of passage, especially from the rumen, is considered to vary with DM intake and forage:concentrate ratio (Colucci et al. 1982), but the data in Table 2 would appear to indicate very similar passage rates $\left(k_{1}\right)$ for the diets, while larger variations of $L$ were observed with the AD model (Table 3 ). The same conclusion can be drawn from the CMRT and TMRT, which were inversely related to intake level for the AD model but not for the MC model.

An examination of Table 4 clearly shows that $A$, CMRT and TMRT obtained with the MC model do not have the same degree of correlation with intake and digestibility as do the AD parameters. On the one hand, the relationship with intake and digestibility would support the superiority of the AD model in predicting the passage rate, but, on the other hand, a better fitting of experimental data would lead to a better interpretation of faecal excretion curves and, probably, an improvement in the passage rate estimate. The real problem is that actual measurements of the rumen passage rate and the CMRT and TMRT are difficult to perform so that it is hard to assess the superiority of a mathematical model in predicting these nutritional variables.

Table 4 also demonstrates that the models describe DM intake and digestibility better than those of NDF. One would expect that the change in physico-chemical (Ehle, 1984; Ehle et al. 1984; Ramanzin et al. 1991 a; Owens \& Hanson, 1992) and fermentation (Robles et al. 1981; Stefanon \& Ovan, 1988) characteristics of feed particles would result in a different pattern of faecal excretion of the mordanted particles in comparison with untreated dietary particles, especially for rations differing greatly in forage:concentrate ratio and level of intake. However, Susmel et al. (P. Susmel, B. Stefanon, C. R. Mills and M. Spanghero, unpublished results) recorded no significant differences in excretion kinetics between meadow hay contaminated with radioactive Cs and the same hay mordanted with Cr. This would appear to indicate that the change in physico-chemical properties of feed particles is not as important as the entire dynamic process of digestion. This consideration was also derived from previous work (Susmel et al. 1990a, 1992 b) and suggested the use of the pattern of $\mathrm{Cr}$ excretion in the faeces to describe the whole digestive process rather than attributing a precise biological meaning to each estimated parameter.

Experimental faecal marker excretion data can also be used to estimate the faecal output (France et al. 1988; Krysl et al. 1988; Moore et al. 1992) and, if the intake is known, the digestibility of the diet; in this case the ability to predict certain parameters using different models is easier to assess, since a comparison can be made directly with measured digestibility values. According to these authors, $F_{\text {op }}$ can be calculated from the ratio of the dose of marker and the scale parameter $A$ and other parameters of the models or as a ratio of dose of marker and the integral of the faecal concentration curve.

In the present trial a large number of animals (dry and lactating cows) and diets were used; marker concentrations in the faeces were corrected for the actual DM intake in order to refer the faecal output directly to indigestibility, or $100-F_{\mathrm{op}}$ as digestibility.

The estimated faecal output, obtained using the defined integral from 0 to $300 \mathrm{~h}$, was very similar between models (Fig. 6) and the regression analysis with the observed digestibility data for each of the models (Figs 4 and 5) revealed high $r^{2}$ values and the bias in the estimates was lower than 3 and $4 \%$ for the $\mathrm{MC}$ and $\mathrm{AD}$ models respectively. According to France $e t$ al (1988) the ability to predict the faecal output is dependent upon the indigestible marker used but not the mathematical model. These authors obtained their results using continuously-fed animals and hourly faecal sampling, experimental conditions rather different from those adopted in the present trial. It is thus important to underline that the technique is still valid for discontinuous feeding, which would mean a 
non-constant production of faeces, one of the most important assumptions of these mathematical models.

Further experimental work is needed to establish the accuracy of the prediction of faecal output in order to utilize this technique as a tool for investigating diet digestibility. The incorporation of diffusion and viscosity concepts (France et al. 1993) into the models could further enhance the effectiveness of the results.

This research was supported by the National Research Council of Italy, Special Project RAISA, Subproject No. 3, Paper No. 2280.

\section{REFERENCES}

Aitchison, E., Gill, M., France, J. \& Dhanoa, M. S. (1986). Comparison of methods to describe the kinetics of digestion and passage of fibre in sheep. Journal of the Science of Food and Agriculture 37, 1065-1072.

Beauchemin, K. A. \& Buchanan-Smith, J. G. (1989). Evaluation of markers, sampling sites and models for estimating rates of passage of silage or hay in dairy cows. Animal Feed Science and Technology 27, 59-75.

Colucci, P. E., Chase, L. E. \& Van Soest, P. J. (1982). Feed intake, apparent diet digestibility and rate of particulate passage in dairy cattle. Journal of Dairy Science 65, 1445-1456.

Colucci, P. E., Macleod, G. K., Grovum, W. L. \& McMillan, I. (1984). Comparative digestion and digesta kinetics in sheep and cattle. Canadian Journal of Animal Science 64 Suppl., 173-174.

Cruickshank, G. J., Poppi, D. P. \& Sykes, A. R. (1989). Theoretical considerations in the estimation of rumen fractional outflow rate from various sampling sites in the digestive tract. British Journal of Nutrition 62, 229-239.

Dhanoa, M. S., France, J. \& Siddons, R. C. (1989). On using a double-exponential model for describing faecal marker concentration curves. British Journal of Nutrition 141, 247-257.

Dhanoa, M. S., Siddons, R. C., France, J. \& Gale, D. L. (1985). A multicompartmental model to describe marker excretion patterns in ruminant faeces. British Journal of Nutrition 53, 663-671.

Ehle, F. R. (1984). Influence of feed particle density on particulate passage from the rumen of Holstein cows. Journal of Dairy Science 67, 693-697.

Ehle, F. R., Bas, F., Barno, B., Martin, R. \& Leone, F. (1984). Particulate rumen turnover rate measurement as influenced by density of passage marker. Journal of Dairy Science 67, 2910-2913.

Eliman, M. E. \& Ørskov, E. R. (1984). Estimation of rates of outflow of protein supplement from the rumen by determining the rate of excretion of chromium-treated protein supplement in faeces. Animal Production 39, $77-80$.

Ellis, W. C., Matis, J. H. \& Lascano, C. (1979). Quantitating ruminal turnover. Federation Proceedings 38, 2702-2706.

Ellis, W. C., Matis, J. H., Pond, K. R., Lascano, C. E. \& Telford, J. P. (1984). Dietary influences on flow rate and digestive capacity. In Herbivore Nutrition in Subtropics and Tropics, pp. 269-293 [F. M. C. Gilchrist and R. I. Mackie, editors]. Johannesburg: The Science Press.

France, J., Dhanoa, M. S., Siddons, R. C., Thornley, J. H. M. \& Poppi, D. P. (1988). Estimating the production of faeces by ruminants from faecal marker concentration curves. Journal of Theoretical Biology 135, 383-391.

France, J., Thornley, J. H. M., Dhanoa, M. S. \& Siddons, R. C. (1985). On the mathematics of digesta flow kinetics. Journal of Theoretical Biology 113, 743-758.

France, J., Thornley, J. H. M., Siddons, R. C. \& Dhanoa, M. S. (1993). On incorporating diffusion and viscosity concepts into compartmental models for analysing faecal marker excretion patterns in ruminants. British Journal of Nutrition 70, 369-378.

Grovum, W. L. \& Williams, V. J. (1973). Rate of passage of digesta in sheep. Passage of marker through the alimentary tract and biological relevance of rate constants derived from the change in concentration of marker in faeces. British Journal of Nutrition 30, 313-329.

Krysl, L. J., Galyean, M. L., Estell, R. E. \& Sowell, B. F. (1988). Estimating digestibility and faecal output in lambs using internal and external markers. Journal of Agricultural Science, Cambridge 111, 19-25.

Lallés, J. P., Delval, E. \& Poncet, C. (1991). Mean retention time of dietary residues within the gastrointestinal tract of young ruminants: a comparison of non-compartmental (algebraical) and compartmental (modelling) estimation methods. Animal Feed Science and Technology 35, 139-159.

Moore, J. A., Pond, K. R., Poore, M. H. \& Goodwin, T. G. (1992). Influence of model and marker on digesta kinetic estimates for sheep. Journal of Animal Science 70, 3528-3540.

Murphy, M. R., Kennedy, P. M. \& Welch, J. G. (1989). Passage and rumination of inert particles varying in size and specific gravity as determined from analysis of faecal appearance using multicompartment models. British Journal of Nutrition 62, 481-492.

Owens, F. N. \& Hanson, C. F. (1992). External and internal markers for appraising site and extent of digestion in ruminants. Journal of Dairy Science 75, 2605-2617. 
Pond, K. R., Ellis, W. C. \& Matis, J. K. (1984). Development and Application of Compartmental Models for Estimating Various Parameters of Digesta Flow in Animals. Texas Agricultural Experimental Station, Animal Science Technical Report no. 84/2. Texas: Texas A \& M Agricultural University.

Pond, K. R., Ellis, W. C., Matis, J., Ferreiro, H. M. \& Sutton, J. D. (1988). Compartment models for estimating attributes of digesta flow in cattle. British Journal of Nutrition 60, 571-595.

Quiroz, R. A., Pond, K. R., Tolley, E. A. \& Johnson, W. L. (1988). Selection among nonlinear models for rate of passage studies in ruminants. Journal of Animal Science 66, 2977-2986.

Ramanzin, M., Bailoni, L. \& Bittante, G. (1990). Effetto del rapporto foraggi:concentrati e del trattamento della paglia con ammoniaca sulla cinetica di trasito dei solidi e dei liquidi in ovini (Effect of forage:concentrate ratio and ammonia treatment of straw on the kinetics of solid and liquid passage in sheep). Zootecnica e Nutrizione Animale 16, 245-254.

Ramanzin, M., Bailoni, L. \& Bittante, G. (1991a). Effetto della densità sul transito e sulla degradabilità ruminale: impiego della composizione densitometrica per la stima della velocità di passaggio e della degradabilità effettiva degli alimenti (Effect of specific gravity (SG) on rumen passage rate and degradation of feed particles: use of specific gravity distribution to estimate passage rate and effective degradability of feedstuffs). In Proceedings of IX Congresso Nazionale ASPA, Rome, 3-7 June, pp. 69-77. Rome: ISMEA-Agricoltura Rierca.

Ramanzin, M., Bittante, G. \& Bailoni, L. $(1991 b)$. Evaluation of different chromium-mordanted wheat straws for passage rate studies. Journal of Dairy Science 74, 2989-2996.

Robles, A. Y., Martz, F. A., Belyea, R. L. \& Warren, W. P. (1981). Preparation and digestibility of alfalfa leaves and stems marked with gold or chromium. Journal of Animal Science 52, 1417-1420.

Statistical Package for the Social Sciences (1988). Base Manual + V2.0. Chicago, IL: SPSS Inc.

Stefanon, B., Mills, C. R. \& Piasentier, E. (1992). Pattern of some internal and external markers along the gastrointestinal tract of cattle. Animal Feed Science and Technology 37, 143-159.

Stefanon, B. \& Ovan, M. (1988). Impiego di bicromato sodico per la valutazione della velocità di transito ruminale degli alimenti (Use of sodium dichromate for the evaluation of feed outflow rate in the rumen). Zootecnica $e$ Nutrizione Animale 15, 431-436.

Stern, M. D., Ortega, M. E. \& Satter, L. D. (1983). Retention time in the rumen and degradation of protein supplements fed to lactating dairy cattle. Journal of Dairy Science 66, 1264-1271.

Susmel, P., Spanghero, M., Stefanon, B., Mills, C. R. \& Cargnelutti, C. (1991). Effect of NDF content and physical form of fescue hay on rumen degradability, intake and rumen turn-over of cows. Animal Production $53,305-313$.

Susmel, P., Spanghero, M., Stefanon, B., Mills, C. R. \& Plazzotta, M. (1992a). N losses, purine N derivatives and intestinal digestible protein requirements of cows at maintenance. Livestock Production Science 36, $213-222$.

Susmel, P., Spanghero, M., Stefanon, B., Mills, C. R. \& Plazzotta, E. (1994a). Digestibility and allantoin excretion in cows fed diets differing in nitrogen content. Livestock Production Science 39, 97-99.

Susmel, P., Stefanon, B., Cargnelutti, C. \& Spanghero, M. (1992 b). Impiego di markers in dose unica: stima del transito ruminale e della digeribilità mediante l'applicazione di diversi modelli matematici (Use of markers in single pulse dose: estimation of rumen outflow and total apparent digestibility using different mathematical models). Zootecnica e Nutrizione Animale 18, 111-123.

Susmel, P., Stefanon, B., Mills, C. R. \& Spanghero, M. (1990a). Applicazione di modelli matematici diversi alle variazioni di concentrazione di un marker indigeribile nelle feci per la valutazione della velocità di transito ruminale dei foraggi (Application of mathematical models to variations in marker concentration in faeces to estimate rumen outflow rate of forages). Zootecnica e Nutrizione Animale 16, 207-218.

Susmel, P., Stefanon, B., Mills, C. R. \& Spanghero, M. (1990 b). Rumen degradability of organic matter, nitrogen and fibre fractions in forages. Animal Production 51, 515-526.

Susmel, P., Stefanon, B., Plazzotta, E., Spanghero, M. \& Mills, C. R. (1994b). The effect of energy and protein intake on the excretion of purine derivatives. Journal of Agricultural Science, Cambridge 123, 257-265.

Uden, P., Colucci, P. E. \& Van Soest, P. J. (1980). Investigation of chromium, cerium and cobalt as markers in digesta. Rate of passage studies. Journal of the Science of Food and Agriculture 31, 625-632. 